\title{
Análisis de variables morfológicas de pavos de traspatio mexicanos (Meleagris gallopavo gallopavo)
} Analysis of morphological variables in Mexican backyard
turkeys (Meleagris gallopavo gallopavo)

Ángel Ríos Utreraa, Sergio Iván Román Ponceb, Alejandra Vélez Izquierdob, Eduardo Cabrera Torresc, Antonio Cantú Covarrubiasd, Lino De la Cruz Colíne, Marina Durán Aguilarf, Jorge Alonso Maldonado Jaquezg, Fernando Edgar Martínez Silvah, Guillermo Martínez Velázquezi, Felipe de Jesús Ruiz Lópezb, Alessandro Bagnatoj, Vicente Eliezer Vega Murilloa

\begin{abstract}
RESUMEN
El objetivo fue evaluar algunas características morfológicas de pavos de traspatio $(n=248)$ provenientes de 126 unidades rurales de producción localizadas en 75 municipios de 24 estados de la República Mexicana. El modelo estadístico incluyó sexo, estado y municipio anidado en estado. Las tres variables explicativas afectaron a todas las variables de respuesta $(P<0.01)$, excepto municipio, que no afectó circunferencia de la pechuga $(P>0.05)$. Los machos tuvieron mayor $(P<0.001)$ longitud corporal $(10.4 \mathrm{~cm}$ más), envergadura $(11.4 \mathrm{~cm}$ más $)$, circunferencia de la pechuga (13.8 cm más), longitud de tarso ( $2.5 \mathrm{~cm}$ más), peso corporal (2.5 $\mathrm{kg}$ más), robustez (9.0 puntos porcentuales más) y solidez (2.8 puntos porcentuales más) que las hembras. Peso corporal mostró estar altamente correlacionado fenotípicamente $(P<0.01)$ con circunferencia de la pechuga tanto en machos $(r=0.74)$ como en hembras $(r=0.71)$. En machos, longitud corporal mostró una correlación baja con longitud del tarso $(r=0.25 ; P<0.01)$, pero en hembras no estuvo correlacionada $(r=0.05 ; P>0.05)$. El peso corporal aumentó $143 \mathrm{~g}(P<0.01)$ en machos y $113 \mathrm{~g}$ en hembras $(P<0.01)$ por cada centímetro que aumentó la circunferencia de la pechuga. Los colores predominantes en el plumaje, la piel y el tarso fueron negro, blanco y café, respectivamente. El pavo de traspatio mexicano presentó dimorfismo sexual significativo y alta correlación fenotípica entre circunferencia de la pechuga y peso corporal.
\end{abstract}

PALABRAS ClaVe: Pavo de traspatio, Morfología, Indices, Correlaciones fenotípicas.

\begin{abstract}
The objective was to evaluate some morphological characteristics of backyard turkeys $(n=248)$ coming from 126 rural production units located in 75 municipalities of 24 States of the Mexican Republic. The statistical model included sex, state, and municipality within state. The three explanatory variables affected all the response variables $(P<0.01)$, except municipality, which did not affect breast circumference $(P>0.05)$. Male turkeys had greater $(P<0.001)$ body length (10.7 cm more), wingspan (11.4 cm more), breast circumference $(13.8 \mathrm{~cm}$ more), shank length $(2.5 \mathrm{~cm}$ more), body weight ( $2.5 \mathrm{~kg}$ more), stockiness (9.0 percentage units more) and massiveness ( 2.8 percentage units more) than female turkeys. Body weight showed to be highly correlated phenotypically $(P<0.01)$ with breast circumference in both males $(r=0.74)$ and females $(r=0.71)$. Body length was lowly correlated with shank length $(r=0.25 ; P<0.01)$ in males, but it was not correlated with shank length in females $(r=0.05 ; P>0.05)$. Body weight increased $143 \mathrm{~g}$ in males $(P<0.01)$ and $113 \mathrm{~g}$ in females $(P<0.01)$ for each centimeter increment in breast circumference. The predominant colors in the plumage, skin and tarsus were black, white and brown, respectively. The Mexican backyard turkey presented significant sexual dimorphism and strong phenotypic correlation between breast circumference and body weight.
\end{abstract}

KEY WORDS: Mexican backyard turkey, Morphology, Indices, Phenotypic correlations.

Recibido el 20 de julio de 2015. Aceptado el 29 de septiembre de 2015.

a Campo Experimental La Posta, INIFAP, km 22.5 carretera federal Veracruz-Córdoba, Paso del Toro, Municipio de Medellín, 94277. Veracruz, México. Teléfono: 01 (229) 262-2222. vega.vicente@inifap.gob.mx. Correspondencia al último autor.

Centro Nacional de Investigación Disciplinaria en Fisiología y Mejoramiento Animal, INIFAP. México.

Campo Experimental Chetumal, CIRSE, INIFAP. México.

Sitio Experimental Aldama, CIRNE, INIFAP. México.

Campo Experimental Valle de México, CIRCE, INIFAP. México.

Facultad de Estudios Superiores Cuautitlán, UNAM. México.

Campo Experimental La Laguna, CIRNOC, INIFAP. México.

Campo Experimental Valles Centrales de Oaxaca, CIRPAS, INIFAP. México.

Campo Experimental Santiago Ixcuintla, CIRPAC, INIFAP. México.

Università degli Studi di Milano, Dipartimento di Scienze e Tecnologie Veterinarie per la Sicurezza Alimentare. Italia. 
La conservación y mejoramiento de especies autóctonas de animales requiere su caracterización morfológica, así como la estimación de parámetros genéticos y fenotípicos de características de importancia económica. Por ejemplo, el conocimiento del tipo de asociación o correlación que guardan las características de importancia económica es fundamental para definir la estrategia adecuada de mejora genética, ya que la selección directa puede ser impráctica o costosa para características difíciles de medir y con baja heredabilidad.

Sin lugar a dudas, el pavo doméstico mexicano (Meleagris gallopavo gallopavo) es un importante reservorio de genes útiles y posee características adaptativas(1) importantes que le permiten habitar y desarrollarse prácticamente en todas las zonas agroecológicas del territorio mexicano. En la última década, diversos estudios han tenido como objetivo la determinación de la diversidad morfológica y genética de pavos de traspatio mexicanos provenientes de algunas regiones específicas de nuestro país, como la Costa de Oaxaca, el municipio de Maní en Yucatán, centro-norte de Chiapas, el estado de Michoacán, y el municipio de Kopala en Puebla(2-9). Sin embargo, es necesaria la evaluación de pavos provenientes de un mayor número de regiones agroecológicas y sistemas de producción.

Por otro lado, solo un estudio ha reportado estimadores de correlaciones fenotípicas para características morfológicas cuantitativas, como peso corporal, circunferencia de la pechuga, longitud del tarso, longitud corporal, altura y longitud de la pierna, de pavos de traspatio mexicanos(7). Los resultados de dicho estudio sugieren que los estimadores de las correlaciones fenotípicas dependen del sexo del ave, ya que los estimadores fueron moderados en machos, pero bajos, e incluso algunos fueron no significativos, en hembras. No obstante, el limitado número de observaciones (menos de 50 para cada sexo) utilizado por Estrada(7) para calcular los estimadores de las correlaciones
Conservation and improvement of native animal species requires morphological characterization, as well as estimation of genetic and phenotypic parameters of economically significant traits. Understanding the types of associations or correlations between traits is fundamental to developing genetic improvement strategies, because direct selection can be impractical or costly for traits that are difficult to measure or of low heritability.

The Mexican domestic turkey (Meleagris gallopavo gallopavo) is an important reservoir of useful genes with notable adaptive traits(1), that allow it to live and develop in almost any of the country's many agro ecological zones. In recent years, a number of studies have addressed the morphological and genetic diversity in Mexican backyard turkeys from certain regions: the coast of the state of Oaxaca; Mani municipality in the state of Yucatan; the north-central portion of the state of Chiapas; the state of Michoacán; and Kopala municipality in the state of Puebla(2-9). This is only a small portion of the country, and studies are needed in many more agro ecological regions and production systems to create a functional database.

Only one study to date has included phenotypic correlation estimates for quantitative morphological characteristics such as body weight, breast circumference, tarsus length, body length, height, and leg length in Mexican backyard turkeys $(7)$. The results suggest that phenotypic correlation estimates depend on the sex of the bird since they were moderate in males, but low in females, and some of the estimates in females were not significant. However, this study used a limited number of observations ( $<50$ per sex) to calculate the estimates. Confirming estimates validity will require additional studies involving larger numbers of observations. The present study objective was to evaluate quantitative and qualitative morphological characteristics of backyard turkeys from twenty-four states in Mexico, and estimate the phenotypic correlations between the quantitative morphological variables. 
fenotípicas, hacen necesario realizar estudios adicionales con un mayor número de observaciones, con el fin de confirmar tal hallazgo. Con base en lo anterior, el objetivo del presente estudio fue evaluar características morfológicas, cuantitativas y cualitativas, de pavos de traspatio provenientes de 24 estados de la República Mexicana, así como estimar las correlaciones fenotípicas entre las variables morfológicas cuantitativas.

Se analizó la información morfológica de 248 pavos de traspatio resultante de un muestreo por oportunidad que involucró 126 unidades
From 2013 to 2014, morphological data from 248 backyard turkeys were collected by opportunity sampling in 126 rural production units located in 75 municipalities (Table 1) in 24 states of Mexico: Baja California Sur, Campeche, Chiapas, Chihuahua, Coahuila, Colima, Mexico City, Durango, Estado de México, Guanajuato, Hidalgo, Jalisco, Morelos, Nayarit, Nuevo León, Oaxaca, Puebla, Querétaro, Quintana Roo, Tabasco, Tamaulipas, Tlaxcala, Veracruz and Zacatecas. This sampling technique was used because of its low cost, minimal time requirements, relative simplicity and production of data from a wide array of individuals. The

Cuadro 1. Municipios muestreados enlistados por estado

Table 1. Sampled municipalities listed by state

\begin{tabular}{|c|c|}
\hline STATE & MUNICIPALITIES \\
\hline Baja California Sur & Comondú, Los Cabos \\
\hline Campeche & Champotón, Escárcega, Tenabo \\
\hline Chiapas & Ángel Albino Corzo, Chanal, Juárez, San Lucas \\
\hline Chihuahua & Janos, Madera \\
\hline Coahuila & Francisco I. Madero, Matamoros, Viesca, Zaragoza \\
\hline Colima & Comala, Manzanillo, Minatitlán \\
\hline Distrito Federal & Milpa Alta \\
\hline Durango & Cuencamé, Lerdo \\
\hline Estado de México & Almoloya de Juárez, Amanalco, Ixtlahuaca, Jocotitlán, Temascalapa, Tequixquiac, San Felipe del Progreso \\
\hline Guanajuato & Abasolo, Comonfort, Huanímaro, Salamanca \\
\hline Hidalgo & Ajacuba, Cuautepec de Hinojosa, Huejutla de Reyes, Santiago de Anaya, Tula de Allende \\
\hline Jalisco & Cabo Corrientes, Cuautitlán de García Barragán, Villa Purificación \\
\hline Morelos & Temixco, Tlaquiltenango \\
\hline Nayarit & Santiago Ixcuintla \\
\hline Nuevo León & Agualeguas, Los Ramones \\
\hline Oaxaca & $\begin{array}{l}\text { Loma Bonita, Magdalena Peñasco, Pinotepa Nacional, San Jerónimo Sosola, San Martín Toxpalan, } \\
\text { San Pedro Amuzgos, San Vicente Coatlán, Santa María Yalina }\end{array}$ \\
\hline Puebla & Hueytamalco, San Martín Texmelucan \\
\hline Querétaro & Jalpan de Serra \\
\hline Quintana Roo & Felipe Carrillo Puerto \\
\hline Tabasco & Huimanguillo, Tacotalpa \\
\hline Tamaulipas & Aldama, Altamira \\
\hline Tlaxcala & Españita, Tlaxco \\
\hline Veracruz & $\begin{array}{l}\text { Acayucan, Álamo Temapache, Alvarado, Ixhuatlán de Madero, Jalacingo, Jáltipan, Medellín, } \\
\text { Soledad de Doblado, Tlacolulan, Tlalixcoyan }\end{array}$ \\
\hline Zacatecas & Guadalupe, Juan Aldama \\
\hline
\end{tabular}


rurales de producción ubicadas en 75 municipios de 24 estados de la República Mexicana: Baja California Sur, Campeche, Chiapas, Chihuahua, Coahuila, Colima, Distrito Federal, Durango, Estado de México, Guanajuato, Hidalgo, Jalisco, Morelos, Nayarit, Nuevo León, Oaxaca, Puebla, Querétaro, Quintana Roo, Tabasco, Tamaulipas, Tlaxcala, Veracruz y Zacatecas. El muestreo por conveniencia se aplicó porque es más barato, demanda menos tiempo, es menos complicado y asegura el muestreo de individuos. Los municipios muestreados se presentan en el Cuadro 1. La información se recolectó de 2013 a 2014 a partir de pavos de ambos sexos (138 machos y 110 hembras), tanto jóvenes como adultos.

Las variables cuantitativas evaluadas fueron: longitud del cuerpo, envergadura, circunferencia de la pechuga, longitud del tarso, peso vivo corporal, robustez y solidez, mientras que las cualitativas fueron: color del plumaje, color de la piel y color del tarso. Las mediciones de las variables cuantitativas se realizaron siguiendo los Lineamientos para la Producción Animal y la Salud de la Organización de las Naciones Unidas para la Alimentación y la Agricultura(10). El peso de los pavos se obtuvo con un dinamómetro colgante con capacidad para $10 \mathrm{~kg}$ (marca PEXA; modelo ECO-DIN 10; precisión $\pm 25 \mathrm{~g}$ ), mientras que longitud del cuerpo, envergadura, circunferencia de la pechuga y longitud del tarso se midieron con una cinta métrica flexible de plástico (marca FIBER-GLASS). Las siete variables cuantitativas analizadas se definieron de la siguiente manera:

Longitud del cuerpo. Se midió como la distancia que existe entre la base del pico y el extremo caudal, a la altura de la glándula uropígea, sin considerar las plumas de la cola, teniendo el pescuezo del ave extendido.

Envergadura. Se midió como la distancia de la falange terminal de un ala a la falange terminal de la otra ala (sin incluir las plumas), manteniendo las alas del ave completamente extendidas. sample included juvenile and adult turkeys of both sexes (138 males and 110 females).

Seven quantitative variables were evaluated: body length, wingspan, breast circumference, tarsus length, live body weight, robustness, and solidity. Three qualitative variables were evaluated: plumage color, skin color, and tarsus color. Measurement of quantitative variables was done following the FAO Guidelines for Animal Production and Health(10). Turkeys were weighed with a $10 \mathrm{~kg}$ capacity hanging scale (ECO-DIN 10; PEXA; accuracy $= \pm 25 \mathrm{~g}$ ). A flexible plastic measuring tape (FIBER-GLASS) was used to collect data on body length, wingspan, breast circumference and tarsus length. The seven quantitative variables were defined as follows:

Body length. The distance between beak base and caudal tip at the level of the uropygial gland, without considering feather length on the tail; measured while extending the neck.

Wingspan. The length from the terminal phalange of one wing to the terminal phalange of the other wing (not including feathers) with the wings completely extended.

Breast circumference. Measured at the level of the crest of the breastbone, extending the measuring tape along the posterior insertion of the wings.

Tarsus length. Metatarsal length measured as the distance from the intertarsal articulation to the metatarsophalangeal articulation.

Body weight. Bird live weight as measured on a hanging scale at the time of the visit to the production unit.

Robustness. (Breast circumference/body length) x 100 .

Solidity. (Body weight/body length) x 100 .

An analysis of variance (ANOVA) was run for each quantitative trait using the GLM procedure 
Circunferencia de la pechuga. Se midió a nivel de la punta de la quilla, pasando la cinta métrica por la parte posterior de la inserción de las alas.

Longitud del tarso. Correspondió al largo del tarso-metatarso y se definió como la distancia de la articulación intertarsiana a la articulación metatarsofalángica.

Peso corporal. Correspondió al peso del ave viva medido con una báscula en el momento en que se realizó la visita a la unidad de producción.

Robustez. Se definió como: (circunferencia de la pechuga/longitud corporal) x 100 .

Solidez. Se definió como: (peso corporal/longitud corporal) x 100 .

Se realizó un análisis de varianza para cada característica cuantitativa con el procedimiento GLM de SAS(11). En todos los casos, el modelo estadístico incluyó sexo, estado y municipio anidado dentro de estado. Matemáticamente, el modelo usado se representa de la siguiente manera:

$y_{i j k l}=\mu+\alpha_{i}+\beta_{j}+\gamma_{k(j)}+\varepsilon_{i j k l}$

Donde: $y_{i j k l}$ es la l-ésima observación de la variable de respuesta (longitud del cuerpo, envergadura, circunferencia de la pechuga, longitud del tarso, peso vivo corporal, robustez o solidez), $\mu$ es la media general, $\alpha_{i}$ es el efecto fijo del i-ésimo sexo $(i=1,2), \beta_{j}$ es el efecto fijo del j-ésimo estado $(j=1, \ldots, 24), \gamma_{k}(j)$ es el efecto fijo del k-ésimo municipio anidado dentro del jésimo estado $(k=1, \ldots, 75)$ y $\varepsilon_{i j k l}$ es el l-ésimo error aleatorio; $\mathrm{y}_{\mathrm{ijkl}} \sim N\left(\mu, \sigma^{2}\right)$.

Las diferencias entre las medias de machos y hembras se estimaron con la opción PDIFF del procedimiento GLM. Adicionalmente, con el procedimiento CORR de SAS(11) se estimaron los coeficientes de correlación de Pearson para las variables longitud del cuerpo, envergadura, circunferencia de la pechuga, longitud del tarso in the SAS statistics package(11). In all cases, the statistical model included sex, state, and municipality nested within state. The model was mathematically represented as:

$y_{i j k l}=\mu+\alpha_{i}+\beta_{j}+\gamma_{k(j)}+\varepsilon_{i j k l}$

where: $y_{i j k l}$ is the I-th observation of the response variable (body length, wingspan, breast circumference, tarsus length, live body weight, robustness, or solidity); $\mu$ is the general mean; $\alpha_{i}$ is the fixed effect of the $i$-th sex $(i=1,2) ; \beta_{j}$ is the fixed effect of the $j$-th state $(j=1, \ldots, 24)$; $\gamma_{k(j)}$ is the fixed effect of the k-th municipality nested within the $\mathrm{j}$-th state $(\mathrm{k}=1, \ldots, 75)$; and $\varepsilon_{\mathrm{ijkl}}$ is the l-th random error; $\mathrm{y}_{\mathrm{ijkl}} \sim N\left(\mu, \sigma^{2}\right)$.

Differences between means of males and females were estimated using the PDIFF option in the GLM procedure. In addition, the CORR procedure was run to estimate the Pearson correlation coefficients among body length, wingspan, breast circumference, tarsus length and body weight. This was done to identify the variables most strongly correlated with body weight. The correlations were estimated independently for males and females, and then for the combined data set of males and females. In response to reports indicating that thoracic perimeter is a good indicator of body weight in different animal species(12), the REG procedure was run to estimate the linear regression coefficient of body weight on breast circumference. Again, this was done independently for males and females, and then for the combined data set of males and females. Finally, the FREQ procedure was applied to calculate the frequency of the categories observed in the field corresponding to each of the studied qualitative traits.

Average weight in the studied animals was 4.6 $\mathrm{kg}$, with a range of 2.5 to $8.7 \mathrm{~kg}$ (Table 2). This is similar to the 2.9 to $8.9 \mathrm{~kg}$ range reported for male and female turkeys in the state of Michoacán(8), but generally lower than the 6 to $20 \mathrm{~kg}$ range found in the Xochimilco region of 
Ángel Ríos Utrera, et al. / Rev Mex Cienc Pecu 2016;7(3):377-389

Cuadro 2. Estadísticas descriptivas de variables morfológicas cuantitativas de pavos de traspatio (datos de machos y hembras agrupados)

Table 2. Descriptive statistics of quantitative morphological variables of backyard turkeys (male and female data grouped)

\begin{tabular}{lcrrrrc}
\hline Variable & $\mathrm{N}$ & Mean & $\mathrm{SD}$ & Min value & Max value & $\mathrm{CV}(\%)$ \\
\hline BL, cm & 248 & 61.6 & 8.8 & 36.0 & 94.0 & 14 \\
Wl, cm & 248 & 66.9 & 11.2 & 34.0 & 95.0 & 17 \\
BRC, cm & 248 & 48.9 & 9.2 & 32.0 & 70.0 & 19 \\
TL, cm & 248 & 13.0 & 1.9 & 9.0 & 17.0 & 15 \\
BW, $\mathrm{kg}$ & 248 & 4.6 & 1.7 & 2.5 & 8.7 & 36 \\
RO, $\%$ & 248 & 79.6 & 11.0 & 49.2 & 111.5 & 14 \\
SO, $\%$ & 248 & 7.4 & 2.2 & 4.1 & 14.4 & 30 \\
\hline
\end{tabular}

$\mathrm{BL}=$ body length; $\mathrm{WI}=$ wingspan; $\mathrm{BRC}=$ breast circumference; $\mathrm{TL}=$ tarsus length; $\mathrm{BW}=$ body weight; $\mathrm{RO}=$ robustness; $\mathrm{SO}=$ solidity.

y peso corporal, con el fin de conocer las variables que se asocian más fuertemente con el peso corporal. Las correlaciones se estimaron para machos y hembras de manera independiente, y para datos conjuntos de machos y hembras. Por último, dado que la literatura científica indica que en diferentes especies animales el perímetro torácico es un buen predictor del peso corporal(12), se estimó el coeficiente de regresión lineal del peso corporal sobre la circunferencia de la pechuga del ave, utilizando el procedimiento REG de SAS(11). Este análisis también se hizo para machos y hembras de manera independiente, y para datos conjuntos de machos y hembras. Las frecuencias de las categorías observadas en campo, correspondientes a cada una de las características cualitativas estudiadas, se calcularon con el procedimiento FREQ de SAS(11).

En el Cuadro 2 se presentan las características descriptivas de las variables cuantitativas estudiadas. Los pavos muestreados pesaron de 2.5 a $8.7 \mathrm{~kg}$, con una media de $4.6 \mathrm{~kg}$. Estos valores son similares a los obtenidos por LópezZavala et $a(8)$, quienes reportaron que el peso corporal de pavos michoacanos (machos y hembras) osciló entre 2.9 y $8.9 \mathrm{~kg}$. En Xochimilco (Distrito Federal) se encontró que el
Mexico City(13). Minimum and maximum values for body length and wingspan were similar, although average wingspan $(67 \mathrm{~cm})$ was slightly greater than average body length $(62 \mathrm{~cm})$. The variation coefficients for body length, wingspan, breast circumference and tarsus length were about two times less than the body weight variation coefficient.

State and sex were significant $(P<0.01)$ sources of variation for all the analyzed quantitative variables. However, municipality affected $(P<0.01)$ body length, wingspan, tarsus length, body weight, robustness and solidity, but not breast circumference.

Sexual dimorphism was clearly present in the sample. Least squares means of the quantitative variables showed males had greater $(P<0.001)$ body length (10.4 cm more), wingspan (11.4 $\mathrm{cm}$ more), breast circumference ( $13.8 \mathrm{~cm}$ more), tarsus length ( $2.5 \mathrm{~cm}$ more), body weight $(2.5 \mathrm{~kg}$ more), robustness (9.0 percentage points more), and solidity ( 2.8 percentage points more) than females (Table 3 ). This agrees with one previous study that found males to have greater weight than females(4), and another that found males to have greater body weight, dorsal length, breast circumference, tarsus length and wing length than females(5). A third study also found 
ANÁLISIS DE VARIABLES MORFOLÓGICAS DE PAVOS DE TRASPATIO MEXICANOS

Cuadro 3. Medias de cuadrados mínimos y errores estándar, por sexo, de variables morfológicas cuantitativas de pavos de traspatio

Table 3. Least squares means ( \pm standard error), by sex, of quantitative morphological variables in backyard turkeys

\begin{tabular}{lccccccc}
\hline Sex & BL $(\mathrm{cm})$ & WI $(\mathrm{cm})$ & BRC $(\mathrm{cm})$ & TL $(\mathrm{cm})$ & BW $(\mathrm{kg})$ & RO $(\%)$ & SO $(\%)$ \\
\hline Females & $55.6 \pm 0.61 \mathrm{~b}$ & $58.4 \pm 0.79 \mathrm{~b}$ & $40.7 \pm 0.77 \mathrm{~b}$ & $11.7 \pm 0.16 \mathrm{~b}$ & $3.2 \pm 0.14 \mathrm{~b}$ & $74 \pm 1.0 \mathrm{~b}$ & $5.9 \pm 0.20 \mathrm{~b}$ \\
Males & $66.0 \pm 0.56 \mathrm{c}$ & $69.8 \pm 0.72 \mathrm{c}$ & $54.5 \pm 0.70 \mathrm{c}$ & $14.2 \pm 0.15^{\mathrm{c}}$ & $5.7 \pm 0.13^{\mathrm{c}}$ & $83 \pm 0.9 \mathrm{c}$ & $8.7 \pm 0.18 \mathrm{c}$ \\
\hline
\end{tabular}

$\mathrm{BL}=$ body length; $\mathrm{WI}=$ wingspan; $\mathrm{BRC}=$ breast circumference; $\mathrm{TL}=$ tarsus length; $\mathrm{BW}=$ body weight; $\mathrm{RO}=$ robustness; $\mathrm{SO}=$ solidity.

b,c Different letter superscripts in the same column indicate difference $(P<0.001)$.

peso corporal de pavos machos y hembras varió de 6 a $20 \mathrm{~kg}(13)$, lo cual contrasta considerablemente con lo hallado en el presente estudio. Los valores mínimos y máximos de longitud corporal y envergadura fueron similares, aunque el valor promedio de envergadura fue un poco mayor que el de longitud corporal (67 vs $62 \mathrm{~cm}$ ). Los coeficientes de variación de longitud corporal, envergadura, circunferencia de la pechuga y longitud del tarso fueron alrededor de dos veces menores que el coeficiente de variación del peso corporal.

Estado y sexo fueron fuentes de variación importantes $(P<0.01)$ para todas las variables cuantitativas analizadas. Por el contrario, municipio afectó significativamente longitud del cuerpo, envergadura, longitud del tarso, peso corporal, robustez y solidez, pero no afectó circunferencia de la pechuga. Las medias de cuadrados mínimos y sus respectivos errores estándar de las variables cuantitativas estudiadas para pavos machos y pavos hembras se presentan en el Cuadro 3. Los machos tuvieron mayor $(P<0.001)$ longitud corporal $(10.4 \mathrm{~cm}$ más), envergadura (11.4 cm más), circunferencia de la pechuga $(13.8 \mathrm{~cm}$ más), longitud de tarso $(2.5 \mathrm{~cm}$ más), peso corporal (2.5 kg más) robustez ( 9.0 puntos porcentuales más) y solidez (2.8 puntos porcentuales más) que las hembras. Canul et a(4) encontraron que pavos machos fueron más pesados que pavos hembras, en concordancia con lo encontrado en el presente estudio. Otros that males had higher values than females in terms of breast circumference (54.03 vs 42.55 $\mathrm{cm})$, tarsus length (15.35 vs $12.08 \mathrm{~cm}$ ) and body weight $(5.02 \mathrm{vs} 2.94 \mathrm{~kg})(7)$. The overall trend of males having higher quantitative variable values than females has also been observed in other countries such as Croatia(14,15) and Nigeria $(16,17)$.

The Pearson correlation coefficients estimated separately for males and females showed body weight and breast circumference to be highly phenotypically correlated $(P<0.01)$ in males $(r=$ $0.74)$ and females $(r=0.71)$ (Table 4). In contrast, body length was unrelated to wingspan

Cuadro 4. Coeficientes de correlación de Pearson para variables morfológicas cuantitativas de machos (debajo de la diagonal) y hembras (arriba de la diagonal)

Table 4. Pearson correlation coefficients for quantitative morphological variables in males (below diagonal) and females (above diagonal) backyard turkeys

\begin{tabular}{lccccc}
\hline & BL & WI & BRC & TL & BW \\
\hline BL & & 0.00 & $0.31 \mathrm{~b}$ & 0.05 & $0.35 \mathrm{~b}$ \\
WI & $0.25 \mathrm{~b}$ & & $0.40 \mathrm{~b}$ & $0.43 \mathrm{~b}$ & $0.25 \mathrm{~b}$ \\
BRC & $0.52 \mathrm{~b}$ & $0.28 \mathrm{~b}$ & & $0.18 \mathrm{c}$ & $0.71 \mathrm{~b}$ \\
TL & $0.29 \mathrm{~b}$ & $0.49 \mathrm{~b}$ & $0.25 \mathrm{~b}$ & & $0.39 \mathrm{~b}$ \\
BW & $0.38 \mathrm{~b}$ & $0.30 \mathrm{~b}$ & $0.74 \mathrm{~b}$ & $0.34 \mathrm{~b}$ & \\
\hline
\end{tabular}

$\mathrm{BL}=$ body length; $\mathrm{WI}=$ wingspan; $\mathrm{BRC}=$ breast circumference; $\mathrm{TL}=$ tarsus length; $\mathrm{BW}=$ body weight

b Highly significant correlation coefficients $(P<0.01)$.

c Significant correlation coefficients $(P<0.05)$. 
autores(5) reportaron que los machos tuvieron mayor peso corporal, longitud dorsal, circunferencia de la pechuga, longitud del tarso y longitud de ala que las hembras. En forma similar, Estrada(7) reportó que pavos machos superaron a pavos hembras en circunferencia de la pechuga (54.03 vs $42.55 \mathrm{~cm}$ ), longitud del tarso $(15.35$ vs $12.08 \mathrm{~cm}$ ) y peso corporal (5.02 vs $2.94 \mathrm{~kg}$ ). La superioridad de pavos machos sobre pavos hembras también ha sido observada en otros países, como Croacia $(14,15)$ y $\operatorname{Nigeria}(16,17)$.

En el Cuadro 4 se muestran los coeficientes de correlación de Pearson estimados a partir de los datos individuales de machos y hembras, mientras que en el Cuadro 5 se presentan los coeficientes de correlación estimados a partir de los datos conjuntos. Peso corporal y circunferencia de la pechuga estuvieron altamente correlacionados fenotípicamente $(P<0.01)$ en machos $(r=0.74)$ y en hembras $(r=0.71)$. En contraste, longitud corporal no mostró relación con envergadura y longitud del tarso en hembras, pero sí estuvo correlacionada con dichas variables en machos, aunque el estimador de la correlación fue bajo. Los estimadores de las correlaciones fenotípicas de peso corporal con longitud corporal $(r=0.38)$, envergadura $(r=0.30)$ y longitud del tarso $(r=$ 0.34) fueron moderados en machos; en contraste, en hembras, los estimadores de las correlaciones fenotípicas de peso corporal con longitud corporal $(r=0.35)$ y longitud del tarso $(r=0.34)$ fueron moderados, pero el estimador de la correlación entre peso corporal y envergadura fue bajo (0.25). Cuando se analizó la información de machos y hembras conjuntamente, todos los coeficientes de correlación fueron diferentes de cero $(P<0.0001)$ y positivos, lo que indica que si incrementa una variable, incrementan las otras. Peso corporal mostró alta correlación fenotípica con circunferencia de la pechuga $(r=0.87)$, pero estuvo medianamente correlacionado con longitud corporal, longitud del tarso y envergadura. Los estimadores de las correlaciones fenotípicas de longitud del cuerpo and tarsus length in females, but was correlated to them in males, though at a low value. The estimates for the phenotypic correlations of body weight with body length ( $r=0.38)$, wingspan $(r=0.30)$, and tarsus length $(r=0.34)$ were moderate in males. For females, estimated values were moderate between body weight and body length $(r=0.35)$ and tarsus length $(r=0.34)$, but low between body weight and wingspan $(r=0.25)$.

When the data for males and females was analyzed as a set, all the correlation coefficients differed from zero $(P<0.0001)$ and were positive, indicating that if one variable increased all the others did as well (Table 5). In this data set, body weight exhibited high phenotypic correlation with body length, tarsus length and wingspan. The phenotypic correlation estimates were low for body weight with wingspan ( $r=$ $0.42)$ and tarsus length $(r=0.49)$.

Correlation coefficient values between these variables have varied among a number of studies done in different countries and with different types of domestic turkeys. In one study done using the $\mathrm{MH}$ meat production turkey line, body weight and body length were found to have a low correlation $(r=0.38)$, while body weight was strongly associated $(r=0.85)$ with breast

Cuadro 5. Coeficientes de correlación de Pearson para variables morfológicas cuantitativas de pavos de traspatio (datos de machos y hembras agrupados)

Table 5. Pearson correlation coefficients for quantitative morphological variables in backyard turkeys; male and female data grouped

\begin{tabular}{lcccc}
\hline & BL & WI & BRC & TL \\
\hline WI & $0.42 \mathrm{~b}$ & & & \\
BRC & $0.69 \mathrm{~b}$ & $0.56 \mathrm{~b}$ & & \\
TL & $0.49 \mathrm{~b}$ & $0.63 \mathrm{~b}$ & $0.57 \mathrm{~b}$ & \\
BW & $0.64 \mathrm{~b}$ & $0.54 \mathrm{~b}$ & $0.87 \mathrm{~b}$ & $0.63 \mathrm{~b}$ \\
\hline
\end{tabular}

$\mathrm{BL}=$ body length; $\mathrm{WI}=$ wingspan; $\mathrm{BRC}=$ breast circumference; $\mathrm{TL}=$ tarsus length; $\mathrm{BW}=$ body weight.

bHighly significant correlation coefficients $(P<0.0001)$. 
Figura 1. Regresión lineal del peso corporal (BW) sobre la circunferencia de la pechuga (BRC) de machos, hembras, y machos y hembras agrupados

Figure 1. Linear regression of body weight (BW) on breast circumference (BRC) in males, females, and males and females grouped
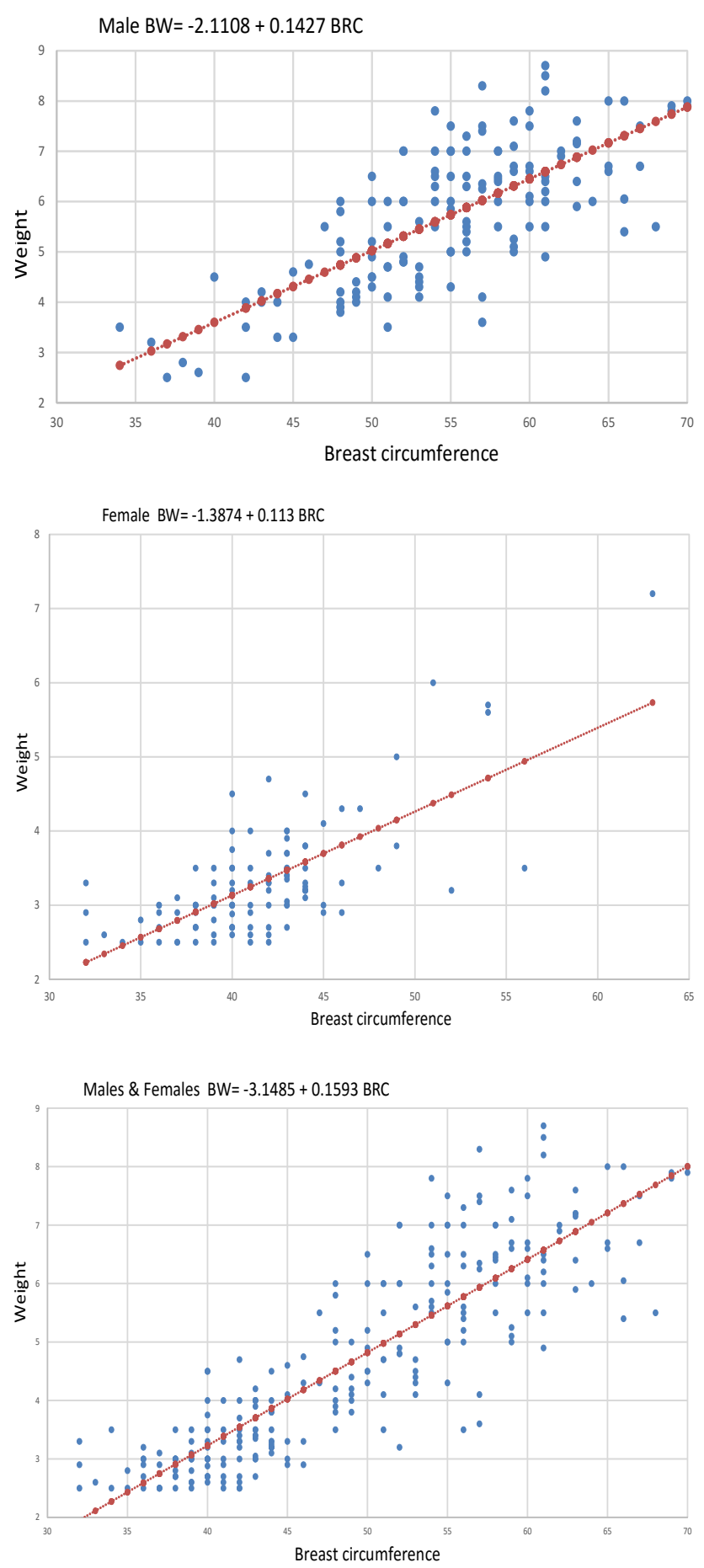

circumference(18). Native Nigerian turkeys (Meleagris gallopavo) were reported to have a strong correlation between body weight and wing length $(r=0.91)$, tarsus length $(r=0.97)$, body length $(r=0.93)$, and breast circumference $(r=0.89)(19)$. In a more recent study done in Tunisia(20), high correlations were identified between body weight and tarsus length ( $r=$ $0.89)$, and body length ( $r=0.90)$. Another study reported moderate correlations between breast circumference and tarsus length in male turkeys ( $r=0.67$ and 0.46 , respectively), but low correlations in females $(r=0.30$ and 0.06 , respectively)(7). Finally, in Nigeria(21) native turkeys (Meleagris gallopavo) were found to have high correlations between body weight and breast circumference $(r=0.83)$, body length $(r=0.90)$, and tarsus length $(r=0.89)$.

The regression analysis showed the regression coefficient of body weight on breast circumference to differ from zero $(P<0.01)$. Body weight in males increased $143 \mathrm{~g}$ for every centimeter increase in breast circumference, and in females it increased $113 \mathrm{~g}$. In the regression analysis of the grouped data, body weight increased $159 \mathrm{~g}$ per centimeter gain in breast circumference. The fit (Figure 1) of the linear regression of body weight (BW) on breast circumference (BRC) was run using one equation for males, one for females and a third for the grouped data:

$$
\begin{aligned}
& \mathrm{BW}=-2.1108+(0.1427 \times \mathrm{BRC}) \text { [males }] \\
& \mathrm{BW}=-1.3874+(0.1130 \times \mathrm{BRC}) \text { [females }] \\
& \mathrm{BW}=-3.1485+(0.1593 \times \mathrm{BRC}) \text { [males \& females] }
\end{aligned}
$$

For males, the standard error was 0.61888 for the intercept and $0.0111 \mathrm{~kg}$ for the regression coefficient; in the females they were 0.4561 and $0.01093 \mathrm{~kg}$, respectively; and in the grouped set they were 0.28691 and $0.00577 \mathrm{~kg}$, respectively. By comparison, 12 -wk old native Nigerian turkeys were found to increase $106 \mathrm{~g}$ in body weight for every centimeter increase in breast circumference(22). The difference 
con envergadura y longitud del tarso fueron bajas ( $r=0.42$ y 0.49 , respectivamente). En una línea de pavos para producción de carne conocida como $\mathrm{MH}$, se encontró(18) que el peso y la longitud corporal tuvieron una baja correlación ( $r=0.38)$; por el contrario, este mismo autor informó que peso corporal tuvo una fuerte asociación fenotípica con circunferencia de la pechuga $(r=0.85)$. Ogah(19) reportó que el peso corporal de pavos nigerianos nativos (Meleagris gallopavo) estuvo fuertemente relacionado con longitud del ala $(r=0.91)$, longitud del tarso $(r=0.97)$, longitud del cuerpo $(r=0.93)$ y circunferencia de la pechuga $(r=0.89)$. En un estudio más reciente realizado en Túnez(20) se encontró que las correlaciones entre peso corporal y longitud del tarso $(r=0.89)$ y entre peso corporal y longitud del cuerpo $(r=0.90)$ fueron altas. Estrada(7) reportó que peso corporal estuvo moderadamente correlacionado con circunferencia de la pechuga y longitud del tarso en pavos machos $(r=0.67$ y 0.46 , respectivamente), pero bajamente correlacionado en pavos hembras $(r=0.30 \mathrm{y}$ 0.06 , respectivamente). En otro trabajo(21) se encontró que el peso corporal de pavos autóctonos (Meleagris gallopavo) tuvo una alta correlación fenotípica con circunferencia de la pechuga $(r=0.83)$, longitud corporal $(r=0.90)$ y longitud del tarso $(r=0.89)$.

Tanto en machos como en hembras y en datos agrupados de machos y hembras, el análisis de regresión mostró que el coeficiente de regresión del peso corporal sobre la circunferencia de la pechuga fue diferente de cero $(P<0.01)$. En machos, el peso corporal aumentó $143 \mathrm{~g}$ por cada centímetro que aumentó la circunferencia de la pechuga, mientras que en hembras aumentó $113 \mathrm{~g}$. El análisis de regresión de los datos agrupados mostró que el peso corporal aumentó $159 \mathrm{~g}$ por cada centímetro que aumentó la circunferencia de la pechuga. En la Figura 1 se muestra el ajuste lineal de la regresión del peso corporal (PC) sobre la circunferencia de la pechuga (CP) en datos de machos, datos de hembras y datos agrupados between this estimated regression coefficient and that in the present results could be due to differences in the average age of the animals in each study.

Thirteen (13) different plumage color phenotypes were documented in the present study, highlighting a wide diversity among the sampled locations. Of the four basic identified colors (white, brown, grey and black), black was the most frequent $(30.8 \%)$, followed by white $(14.7 \%)$, brown and then grey. Nine combinations of these four colors were identified (color order does not indicate relative predominance), the most frequent being "black with white" (18.1\%), followed by "black with white and brown" (10.2\%), "white with brown" (5.8\%), and "black with white and grey" $(4.9 \%)$. On the coast of Oaxaca state, the most frequent colors in turkey plumage were black (29.2 \%) and "white with black" $(30.3 \%)^{(2)}$, whereas in the state of Yucatan the predominant colors were black and "black with brown and white"(4). Black was also found to be the predominant color among turkeys in the state of Puebla, both in males (46.7 \%) and females (52.2\%)(7), and among native turkeys in Croatia(15) and Morocco(23).

Among the five skin colors observed in the studied sample, white was the most common $(81 \%)$, followed by yellow (11\%), and pink (3.9\%). Of the nine observed tarsus colors, the three most frequent were brown $(31.3 \%)$, white $(26.4 \%)$ and black (20.5\%), although pink, red, purple, green, yellow and grey were also present. This contrasts with the six tarsus colors documented on the coast of Oaxaca, white being the most frequent $(2)$, and the four found in Yucatan, pink being most common(4).

The present results indicated the presence of five main distinguishing aspects among the sampled Mexican backyard turkeys. Sexual dimorphism was notable, with clear morphological distinction between males and females. Breast circumference and body weight were highly correlated in both males and 
de machos y hembras. Las ecuaciones de regresión estimadas fueron:

$$
\begin{aligned}
& P C=-2.1108+(0.1427 \times C P) \text { [machos }] \\
& P C=-1.3874+(0.1130 \times C P) \text { [hembras }] \\
& P C=-3.1485+(0.1593 \times C P)[\text { machos y hembras }]
\end{aligned}
$$

Los errores estándar del intercepto y del coeficiente de regresión fueron: 0.61888 y $0.01119,0.4561$ y 0.01093 , y 0.28691 y 0.00577 $\mathrm{kg}$, para datos de machos, datos de hembras y datos agrupados de machos y hembras, respectivamente. Durosaro et $a(22)$ reportaron que pavos nigerianos nativos de 12 semanas de edad aumentaron $106 \mathrm{~g}$ de peso corporal por cada centímetro que aumentó la circunferencia de la pechuga. La diferencia entre el coeficiente de regresión estimado por estos autores y el reportado en el presente estudio se pudo deber a la diferencia en la edad promedio de los pavos de ambos estudios.

Con respecto al color del plumaje, el presente estudio reveló la existencia de 13 fenotipos, indicando una amplia variación fenotípica en dicha característica. Se encontraron cuatro colores básicos: blanco, café, gris y negro, de los cuales el más frecuente fue el color negro $(30.8 \%)$, seguido del color blanco (14.7\%), mientras que los colores café y gris ocuparon el tercer y cuarto lugar, respectivamente. Adicionalmente, se encontraron nueve combinaciones diferentes de estos cuatro colores básicos; la combinación de colores más frecuente fue "negro con blanco" (18.1 \%), seguida de las combinaciones "negro con blanco y café" (10.2\%), "blanco con café" (5.8 \%) y "negro con blanco y gris" (4.9\%). En el caso de las combinaciones de colores encontradas en el plumaje, el orden de los colores proporcionado en el presente estudio es irrelevante y no representa la predominancia de algún color en particular. Camacho-Escobar et $a(2)$ reportaron que en la costa de Oaxaca los colores más frecuentes en el plumaje de pavos de traspatio fueron negro $(29.2 \%)$ y females, but for other traits the magnitude of the phenotypic correlation estimate was sexdependent. Black and "black with white" turkeys were the most common, most of the turkeys had white skin, and brown was the most frequent tarsus color.

\section{ACKNOWLEDGEMENTS}

The research was partially financed by INIFAP through project No. 10551832012, "Identificación de los recursos genéticos pecuarios para su evaluación, conservación y utilización sustentable en México. Aves y Cerdos", and by the "Programa de Cooperación Científica y Tecnológica México-Italia 2014" through the project "La variabilidad genética en las razas avícolas autóctonas italianas y mexicanas: genética, el análisis filogenético y la interacción genotipo-ambiente". Thanks to Lorenzo Granados Zurita, Sara Olazarán Jenkins, Alfredo Arroyo Lara, Héctor Velázquez Ocaña and Maribel Torres Niño for assistance with identifying backyard turkey production units, measuring animal morphology and entering field data.

End of english version

"blanco con negro" (30.3\%). En Yucatán(4) observaron que la mayor proporción de pavos tuvieron plumaje de color negro y "negro con café y blanco". De manera similar, en el estado de Puebla el color predominante fue el negro, tanto en machos (46.7 \%) como hembras (52.2 \%)(7). En Croacia(15) y Marruecos(23) también se ha encontrado que el color negro es el más abundante en el plumaje de pavos autóctonos.

Se observaron cinco colores diferentes en la piel de los pavos de traspatio. Los pavos con piel de color blanco fueron los que predominaron 
(81\%), seguidos por los pavos con piel de color amarillo (11\%) y rosa (3.9\%). Los colores más observados en los tarsos de los pavos fueron: café ( $31.3 \%)$, blanco ( $26.4 \%$ ) y negro $(20.5 \%)$, aunque también se observaron colores como rosa, rojo, morado, verde, amarillo y gris, identificando nueve colores en total. En la Costa de Oaxaca(2) observaron seis colores en los tarsos de pavos autóctonos, pero el color más común fue el blanco. En contraste, en Yucatán(4) solo encontraron cuatro colores (blanco, rosado, gris y negro) en los tarsos, siendo el rosado el más frecuente.

Las variables estudiadas mostraron que: 1) el pavo de traspatio mexicano presenta una diferenciación morfológica importante entre machos y hembras (dimorfismo sexual), 2) la circunferencia de la pechuga y el peso corporal estuvieron altamente correlacionados tanto en machos como en hembras; sin embargo, para otras características la magnitud del estimador de la correlación fenotípica dependió del sexo, 3) pavos con plumaje de color negro y "negro con blanco" fueron predominantes, 4) la mayoría de los pavos tuvieron piel blanca, y 5) el color café fue el más común en sus patas.

\section{AGRADECIMIENTOS}

Al INIFAP por el financiamiento del proyecto fiscal No. 10551832012, "Identificación de los recursos genéticos pecuarios para su evaluación, conservación y utilización sustentable en México. Aves y Cerdos", y al "Programa de Cooperación Científica y Tecnológica México-Italia 2014" por el apoyo para la realización del proyecto "La variabilidad genética en las razas avícolas autóctonas italianas y mexicanas: genética, el análisis filogenético y la interacción genotipoambiente", así como a los M.C. Lorenzo Granados Zurita, Sara Olazarán Jenkins y Alfredo Arroyo Lara, al Ingeniero Agrónomo Zootecnista Héctor Velázquez Ocaña y a Maribel Torres Niño por su colaboración en la localización de las unidades de producción de pavos de traspatio, la medición morfológica de los animales y la captura de datos en campo.

\section{LITERATURA CITADA}

1. Camacho-Escobar MA, Ramírez-Cancino L, Lira-Torres I, Hernández-Sánchez V. Phenotypic characterization of the Guajolote (Meleagris gallopavo gallopavo) in Mexico. Anim Genet Resour Inform 2008;43:59-66.

2. Camacho-Escobar MA, Hernández-Sánchez V, RamírezCancino L, Sánchez-Bernal EI, Arroyo-Ledezma J. Characterization of backyard guajolotes (Meleagris gallopavo gallopavo) in tropical zones of Mexico. Livest Res Rural Develop 2008;20(4). http://www.Irrd.cipav.org.co/Irrd20/4/ cama20050.htm. Consultado junio 5, 2015.

3. Camacho-Escobar MA, Pérez-Lara E, Arroyo-Ledezma J, Jiménez-Hidalgo $E$. Diferencias y similitudes entre guajolote silvestre y de traspatio (Meleagris gallopavo). Temas Cienc Tec 2009;13(38):53-62.

4. Canul SM, Sierra VA, Mena DO, Ortiz OJ, Zamora BR, Durán SL. Contribución a la caracterización fenotípica del Meleagris gallopavo en la zona sur de Yucatán, México. AICA 2011;1:284-287.

5 Cigarroa-Vázquez F, Herrera-Haro JG, Ruiz-Sesma B, CucaGarcía JM, Rojas-Martínez RI, Lemus-Flores C. Caracterización fenotípica del guajolote autóctono (Meleagris gallopavo) y sistema de producción en la región centro norte de Chiapas, México. Agrociencia 2013;47:579-591.

6. Chassin-Noria O, López-Zavala R, Cano-Camacho H, SuárezCorona E, Juárez-Caratachea A, Zavala-Páramo MG. Diversidad y similitud genética entre poblaciones de guajolotes mexicanos utilizando un método de amplificación aleatorio de ADN polimórfico (RAPD). Téc Pecu Méx 2005;43(3):415-424.

7. Estrada MA. Caracterización fenotípica, manejo y usos del pavo doméstico (Meleagris gallopavo gallopavo) en la comunidad indígena de Kapola en la sierra nororiental del estado de Puebla, México [tesis de maestría]. Puebla, Pue., México. Colegio de Postgraduados; 2007.

8. López-Zavala R, Monterrubio-Rico TC, Cano-Camacho $\mathrm{H}$, Chassin-Noria O, Aguilera-Reyes U, Zavala-Páramo MG. Caracterización de sistemas de producción del guajolote (Meleagris gallopavo gallopavo) de traspatio en las regiones fisiográficas del estado de Michoacán, México. Téc Pecu Méx 2008;46(3):303-316.

9. López-Zavala R, Cano-Camacho H, Chassin-Noria O, Oyamad $\mathrm{K}$, Vázquez-Marrufo G, Zavala-Páramo MA. Diversidad genética y estructura de poblaciones de pavos domésticos mexicanos. Rev Mex Cienc Pecu 2013;4(4):417-434.

10. FAO (Food and Agriculture Organization of the United Nations). Phenotypic characterization of animal genetic resources. FAO Animal Production and Health Guidelines No. 11. Rome. 2012.

11. SAS. Statistical Analysis System, User's Guide. Cary NC, USA. SAS Inst. Inc. 2012.

12. Contreras G, Chirinos Z, Molero E, Paéz A. Medidas corporales e índices zoométricos de toros Criollo Limonero de Venezuela. Zootecnia Trop 2012;30(2):175-181. 


\section{ANÁLISIS DE VARIABLES MORFOLÓGICAS DE PAVOS DE TRASPATIO MEXICANOS}

13. Losada H, Rivera J, Cortés J, Castillo A, González RO, Herrera J. Un análisis de sistemas de producción de guajolotes (Meleagridis gallipavo) en el espacio suburbano de la delegación de Xochimilco al sur de la Ciudad de México. Livest Res Rural Develop 2006;18(4). http:// www.Irrd.cipav.org.co/Irrd18/4/losa18052.htm. Consultado junio 5, 2015.

14. Janječić Z, Mužic S. Phenotypic traits in Zagorje turkey. Agriculture 2007;13(1):205-208.

15. Kabalin $A E$, Menčik $S$, Ostović $M$, Štoković I, Grgas $A$, Horvath S, Balenović T, Sušić V, Karadjole I, Pavičić Z. Morphological characteristics of Dalmatian turkey. Preliminary results. Maced J Anim Sci 2012;2(3):277-280.

16. Ilori BM, Peters SO, Ikeobi CON, Bamgbose AM, Isidahomen $\mathrm{CE}$, Ozoje MO. Comparative assessment of growth in pure and crossbred turkeys in a humid tropical environment. Int J Poultry Sci 2010;9(4):368-375.

17. Yakubu A, Peters SO, Ilori BM, Imumorin IG, Adeleke MA, Takeet MI, Ozoje MO, Ikeobi CON, Adebambo OA. Multifactorial discriminant analysis of morphological and heattolerant traits in indigenous, exotic and cross-bred turkeys in Nigeria. Anim Genet Resour 2012;50:21-27.
18. Oblakova M. Characteristic of some productive indexes of turkey lines at the age of 20 weeks. Bulg J Agric Sci 2006;12:133-143.

19. Ogah DM. Assessing size and conformation of the body of Nigerian indigenous turkey. Slovak J Anim Sci 2011;44(1):2127.

20. Djebbi A, M'hamdi N, Haddad I, Chriki A. Phenotypic characterization of the indigenous turkey (Meleagris gallopavo) in the North West Regions of Tunisia. Sci Agri 2014;2(1):51-56.

21. Oyegunle 00. Genetic, phenotypic and environmental correlation estimates among physical body traits of three turkey genotypes. Int J Agric Food Sci 2013;4(1-2):484491.

22. Durosaro SO, Oyetade MS, Ilori BM, Adenaike AS, Olowofeso $\mathrm{O}$, Wheto $\mathrm{M}$, et al. Estimation of body weight of Nigerian local turkeys from zoometrical measurements at 4, 8 and 12 weeks of age. Global J Sci Front Res 2013;13(1):1-4.

23. Benabdeljelil K, Arfaoui T. Characterization of Beldi chicken and turkeys in rural poultry flocks of Morocco. Current state and future outlook. Anim Genet Resour 2001;31:87-95. 